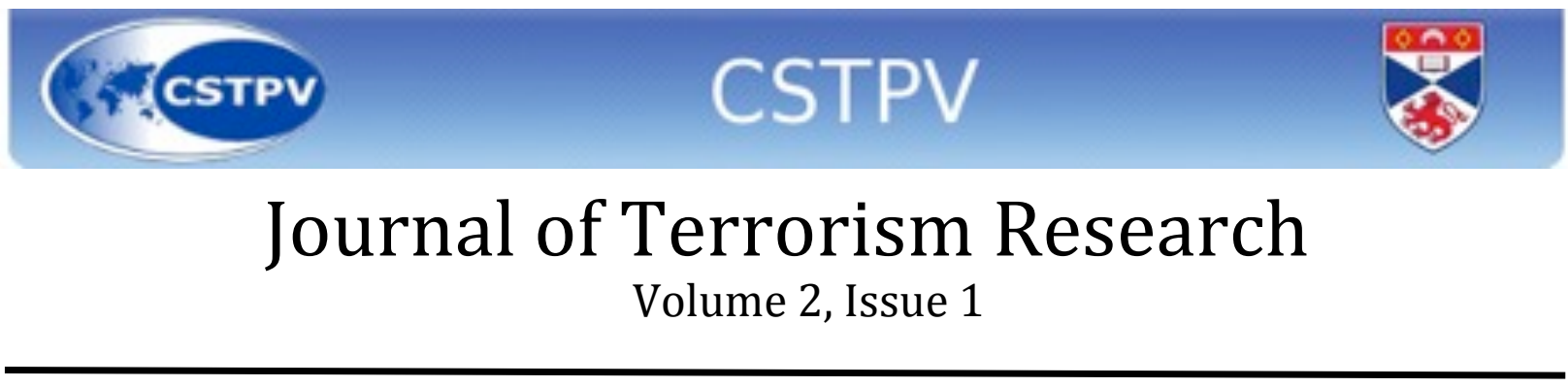

\title{
Opinion Piece - Revolts in the Arab world: is it bad news for Islamic terrorists?
}

\section{by Eugenio Lilli}

\section{King's College London}

\section{London, UK}

Everything started when a young man set himself on fire in the provincial town of Sidi Bouzid, Tunisia. Mohamed Bouazizi, this was his name, was selling fruit and vegetables on the street without a license. After a policewoman stopped him and confiscated his cart and produce, he felt so angry and desperate that he took that drastic decision. It was December $17^{\text {th }}, 2010$. Since then a long series of demonstrations, riots and revolts have quickly and unabatedly spread from Tunisia throughout the Arab world. Tunisia, Algeria, Libya, Egypt, Jordan, Yemen, Oman and Bahrain, among others, were all affected in one way or another by these events. Tunisia's President Zine El Abidine Ben Ali was ousted and Egypt's President Hosni Mubarak experienced the same fate.

Should the West be worried that the events currently unfolding in the region will jeopardize its global effort in fighting international Islamic terrorism?

The common argument is that the chaos created by these revolutions will play into the hands of fundamentalist Islamic groups, who will seize the opportunity to fill the resulting power vacuum. This fear has been fuelled for decades by authoritarian regimes in order to obtain support from the West, and above all from the United States, to prolong their iron-fist rule. Recently, former Egyptian President Mubarak complained during an interview that he was fed up of ruling Egypt, "but if I resign now, there will be chaos. And I'm afraid the Muslim Brotherhood will take over". His counterpart in Libya, Colonel Muammar Gaddafi, warned that "It is obvious now that this issue is run by al Qaeda" and that the protesters are young people who are being manipulated by al Qaeda's Osama bin Laden. The intended audience of these statements is clearly not the Arab masses but rather the Western governments.

There are several reasons why the grim scenarios foreseen by Arab dictators and some of their Western supporters will not be likely to materialize. First of all, jihadist violent rhetoric has not ranked, so far, as one of the main reasons that brought so many people into the streets. Poverty, economic inequality, unemployment, greater political freedom, oppression and disgust for officials' corruption are all more pressing issues than any fundamentalist religious one. A second young man in Tunisia who killed himself in protest allegedly shouted "no for misery, no for 


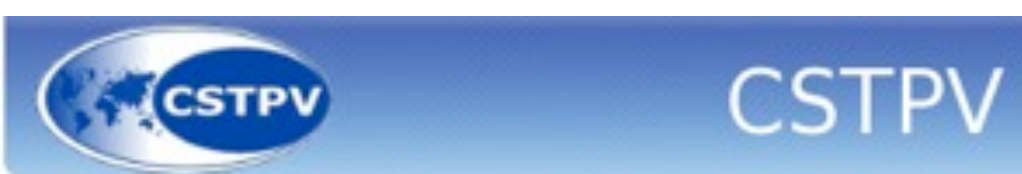

\title{
Journal of Terrorism Research
}

\author{
Volume 2, Issue 1
}

unemployment" before he electrocuted himself. In addition, neither al Qaeda nor any other Islamist terrorist group has played any relevant role during these demonstrations. Osama bin Laden has been silent. While the statements issued by his Egyptian deputy, Ayman al-Zawahri, apparently had no significant resonance.

On the contrary, there are promising elements suggesting that these revolts in Arab countries will strike severe blows to terrorist organizations such as al Qaeda. In fact, two critical tenants of the Islamist terrorists' narrative are that change in the Arab world can be only achieved by violent action and that Arab dictators are puppets controlled by the West, namely by the United States.

As far as the first tenant is concerned, the nature and the outcome of these protests have hitherto disavowed such a claim. Most of the demonstrations were peaceful in nature and those which turned violent, and eventually resorted to the use of force, did that mainly in response to governmental crude repression- Libya being a clear example. Although not all the demonstrations have brought substantial political change, to date two succeeded in toppling dictators. In particular, Egyptian protesters through largely peaceful actions achieved in a few weeks the goal of driving Mubarak out of office; a goal that al-Zawahri and other like-minded terrorists could not achieve in decades of bloody and violent jihad.

As for the second tenant, the West, and the United States in particular, is indeed responsible of cutting deals with oppressive and autocratic regimes in the naïve hope of keeping at bay the spread of fundamentalist Islam. However, although slowly and cautiously, some may argue too slowly and too cautiously, the United States eventually took side with the protesters. US President Barack Obama publicly stated in February that he was "deeply concerned by reports of violence in Bahrain, Libya and Yemen", and that "the United States condemns the use of violence by governments against peaceful protesters in those countries and wherever else it may occur". Then, after additional evidence about extremely repressive actions, he also bluntly urged Colonel Gaddafi "to step down" from power. Some public statements of support are certainly not enough to delete years of funding and the propping up of corrupt and cruel dictatorships but they are undoubtedly a first step in the right direction.

Al Qaeda, and Islamic fundamentalists in general, should be extremely worried about another aspect of these revolts. From what we hear and read, protesters are calling for the institution of some form of democracy in their countries. Democracy is bad news for terrorists. Democracy, in fact, offers institutional and peaceful channels to express public grievances, whether these be political, economic or social in nature. A democratic political system, therefore, noticeably reduces the appeal of violent terrorist strategies and markedly dries up the pool of new recruits. 


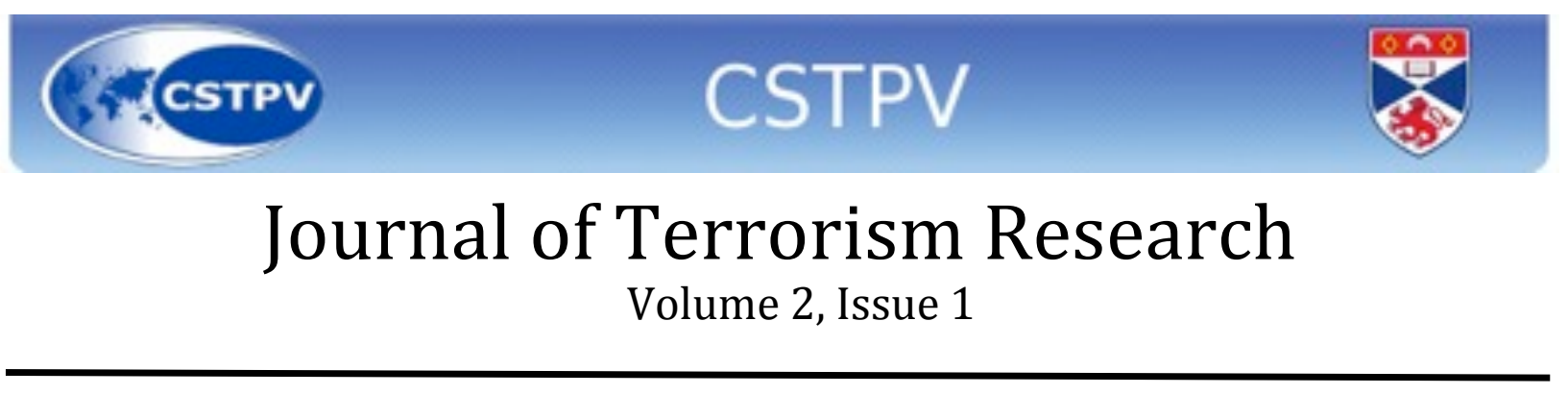

Indeed, the necessity of killing someone, or even to kill yourself in the process, in order to achieve a specific goal looks less and less evident.

Make no mistake, democracy is no panacea. It will not necessarily resolve economic and social problems, thus generating disillusion and frustration likely to lead to new social unrest. Revolutions may be also hijacked by illiberal forces and therefore derailed from their original democratic program. However, democracy in Arab countries is still one of the best weapons to fight the threat of Islamic terrorism. This is why the West should take the lead in helping these recently born-again states to grow prosperous and stable. Although, it is critically important that Western assistance be consistent, whole-hearted and without any hidden strings attached.

Eugenio Lilli is currently a PhD student at the King's College's War Studies Department. His research focuses on the history of US foreign policy and on the impact of the Obama administration on the US Global War on Terror. 